\title{
Cytotoxicity of Dental Adhesives In Vitro
}

\author{
Elisabeth A. Koulaouzidou \\ Maria Helvatjoglu-Antoniades ${ }^{b}$ \\ George Palaghias ${ }^{b}$ \\ Artemis Karanika-Koumab \\ Dimitrios Antoniades ${ }^{c}$
}

\section{ABSTRACT}

Objectives: The purpose of this study was to evaluate the cytotoxic effect of six dental adhesives (Admira Bond, Clearfil Liner Bond 2V, ED Primer II, Fuji Bond LC, Gluma Comfort Bond, and NanoBond) applied to cell cultures.

Methods: The experiments were performed on two cell lines, rat pulp cells (RPC-C2A) and human lung fibroblasts (MRC5). Samples of the adhesives were light-cured and placed in culture medium for 24 hours. The extraction media was applied on the RPC-C2A and the MRC5 cells. Complete medium was used as a control. Cytotoxicity was evaluated with a modified sulforhodamine B (SRB) assay after 24 hours of exposure.

Results: The cell survival of RPC-C2A cells exposed to Fuji Bond LC, NanoBond, Clearfil Liner Bond 2V, ED Primer II, Admira Bond and Gluma Comfort Bond was 73\%, 67\%, 50\%, 20\%, 18\% and 5\% respectively, relative to the cell survival with the control medium. In the MRC5 cell line, the relative survival was $98 \%, 80 \%, 72 \%, 41 \%, 19 \%$ and $7 \%$ after exposure to NanoBond, Fuji Bond LC, Clearfil Liner Bond 2V, ED Primer II, Admira Bond and Gluma Comfort Bond, respectively.

Conclusions: Different types of dental adhesives showed different cytotoxic effects on cells in vitro. The self-etch adhesives were superior in terms of cytotoxicity. The different cytotoxic effects of dental adhesives should be considered when selecting an appropriate adhesive for operative restorations. (Eur J Dent 2009;3:3-9)

Key words: Cell culture; Cytotoxicity; Dental adhesives; In vitro; SRB-assay.

- a Lecturer, Department of Operative Dentistry, Faculty of Dentistry, Aristotle University of Thessaloniki, Greece.

b Associate Professor, Department of Operative Dentistry, Faculty of Dentistry, Aristotle University of Thessaloniki, Greece.

c Professor, Department of Oral Medicine/ Pathology, Faculty of Dentistry, Aristotle University of Thessaloniki, Greece.

- Corresponding author: Elisabeth A. Koulaouzidou 1 Xenofontos street, GR 55132 Kalamaria,

Thessaloniki, Greece.

Phone : +30 2310482233

Fax : $\quad+302310999616$

E-mail: koulaouz@dent.auth.gr

\section{INTRODUCTION}

In the selection of dental materials, biological compatibility is of primary importance, as contact or interaction with oral tissues and body fluids may cause local and/or systemic adverse effects. It has been reported that dental adhesives release substances that have biological effects and toxic potencies. ${ }^{1,2}$ The effective toxicity of adhesives is reduced but often not eliminated by the presence of dentin. ${ }^{1}$ There are several reasons to suspect that dental resins may alter pulpal physiology. Adhesive systems are usually placed on etched 
dentin or, in the case of self-etch adhesives, on cut dentin that is permeable. The different compositions of many adhesives and the variable sequence of their application on dentin result in different resin-dentin interface features and resin tags may form in the dentinal tubules. It is expected that the hybrid layer would hermetically seal the interface between the restorative material and the cavity walls, preventing micro-leakage, marginal staining, secondary caries, and consequently inflammatory pulpal response. ${ }^{3,4}$ However, several in vitro and in vivo studies have demonstrated that after application of bonding agents on the conditioned dentin, uncured residual resin components may diffuse across the subjacent dentinal tubules and reach the pulp.

The application of adhesive systems, which form a hybrid layer with the collagen matrix of dentin, has been suggested as a pulp capping procedure. ${ }^{5}$ Recently, adhesives have been proposed for use in the root canal system to optimize the strengths of bonds between endodontic filling materials and the radicular dentin, or posts and to strengthen endodontically treated teeth. ${ }^{6,7}$

In most cases, dental adhesives may come in direct contact with the soft and/or hard tissues for a prolonged period of time and might affect the surrounding tissues or could also delay healing.

Several in vitro tests have been used for the evaluation of the biological effects of dental adhesives. ${ }^{8-13}$ Generally, in vitro tests using cell cultures provide rapid, sensitive, inexpensive, convenient and repeatable means of screening and ranking materials.

New adhesive systems with different compositions have been introduced in clinical practice, and their biocompatibility needs to be investigated. The aim of this in vitro study was to evaluate the cytotoxicity of six contemporary dental adhesives applied to two established cell lines. Since the composition and the proportions of ingredients vary across the adhesives, the hypothesis tested was that the different materials have different cytotoxic profiles.

\section{MATERIALS AND METHODS}

Dental adhesives

Six dental adhesives were tested: Admira Bond (VOCO), Clearfil Liner Bond 2V (Kuraray), ED Primer II (Kuraray), Fuji Bond LC (GC Corporation), Gluma
Comfort Bond (Heraeus/Kulzer) and NanoBond (Jeneric/Pentron).

The composition and manufacturers of the tested materials are listed in Table 1.

Cell lines and culture conditions

Two fibroblastic cell lines, RPC-C2A (rat pulp cells) and MRC5 (human lung fibroblasts) were used. The MRC5 cells were obtained from Theagenion Cancer Hospital Tissue Culture Bank and the RPC-C2A cells were a generous gift from Prof. S. Kasugai (Department of Pharmacology, Faculty of Dentistry, Tokyo Medical and Dental University, Japan). Cells were grown as monolayer cultures in $75 \mathrm{~cm}^{2}$ cell culture flasks (Costar/Corning, Cambridge, MA, USA), and they were subcultured twice per week at $37^{\circ} \mathrm{C}$ in an atmosphere containing $5 \% \mathrm{CO}_{2}$ in the air and $100 \%$ relative humidity. The culture medium was Dulbecco's modified Eagle medium (DMEM, Gibco, Glasgow, UK), supplemented with 10\% fetal bovine serum (FBS, Gibco, Glasgow, UK), $100 \mu \mathrm{g} / \mathrm{mL}$ streptomycin and $100 \mathrm{IU} / \mathrm{mL}$ penicillin.

\section{Cell inoculation}

Adherent cells at a logarithmic growth phase, were detached by the addition of $2-3 \mathrm{~mL}$ of a $0.05 \%$ trypsin (Gibco, 1:250) and 0.02\% EDTA mixture and incubated for $2-5 \mathrm{~min}$ at $37^{\circ} \mathrm{C}$. Cells were plated in 96-well plates (Costar/Corning, Cambridge) at a density of 4,000 cells (in $100 \mu \mathrm{L}$ of culture medium) per well (well growth area $0.32 \mathrm{~cm}^{2}$ ) and were left for 24 hours in an incubator to resume exponential growth.

Test materials and cell treatment

Test materials were prepared according to the procedure followed in a previous study. ${ }^{10}$ In brief, $100 \mu \mathrm{L}$ of each adhesive was applied in $10 \mathrm{ml}$ sterile vials and light cured by Astralis (Vivadent/Ivoclar, Schaan, Liechtenstein) for $40 \mathrm{~s}$. Then, DMEM (5 $\mathrm{mL}$ per vial) was added and left at $37^{\circ} \mathrm{C}$ for 24 hours. The extract medium was sterile filtered through a $0.22 \mu \mathrm{m}$ syringe filter. A volume of 100 $\mu \mathrm{L}$ of extract medium was added to the cells (final volume $200 \mu \mathrm{L}$ ) and incubated for an additional 24 hours. Wells treated with $100 \mu \mathrm{L}$ of DMEM were used as negative controls. Six replicate wells for each adhesive were prepared. At the end of the incubation period, cell numbers were estimated 
Table 1. Composition and manufacturers of the dental adhesives tested.

\begin{tabular}{|c|c|c|}
\hline Material & Ingredients & Manufacturer \\
\hline $\begin{array}{l}\text { Admira bond } \\
\text { (etch\& rinse agent) }\end{array}$ & $\begin{array}{c}\text { 2-hydroxyethyl methacrylate (HEMA) } 11-14 \% \\
\text { Ormocerszz Aromatic and aliphatic dimethacrylates } \\
\text { Butylated hydroxytoluene (BHT) Organic acidsz } \\
\text { Aceton } 60 \%\end{array}$ & $\begin{array}{l}\text { VOCO GmbH } \\
\text { Germany }\end{array}$ \\
\hline $\begin{array}{l}\text { Clearfil Liner Bond } 2 \mathrm{~V} \\
\text { (two component, one-step } \\
\text { self-etch system) }\end{array}$ & $\begin{array}{c}\text { Primer A: } \\
\text { 10-Methacryloyloxydecyl dihydrogen phosphate (MDP) } \\
\text { 2-Hydroxyethyl methacrylate (HEMA) Water, } \\
\text { photoinitiator, accelerators. } \\
\text { Primer B: AP-X } \\
\text { Bond A: 2-Hydroxyethyl methacrylate (HEMA), } \\
\text { 10-Methacryloyloxydecyl dihydrogen phosphate (MDP), } \\
\text { Dimethacrylates, photoinitiator, accelerators }\end{array}$ & $\begin{array}{c}\text { Kuraray Europe } \mathrm{GmbH} \\
\text { Germany }\end{array}$ \\
\hline $\begin{array}{l}\text { ED Primer II (Panavia F2.0) } \\
\text { (two components, one-step } \\
\text { self-etch system) }\end{array}$ & $\begin{array}{l}\text { Liquid A: 2-hydroxyethyl methacrylate (HEMA) } \\
\text { 10-Methacryloyloxydecyl dihydrogen phosphate (MDP) } \\
\text { N-Methacryloyl 5-Aminosalicylic acid } \\
\text { N,N-Diethanol P-Toluidine } \\
\text { Water } \\
\text { Liquid B: N-Methacryloyl 5-Aminosalicylic acid } \\
\text { Sodium benzen sulfinate } \\
\text { N,N-Diethanol P-Toluidine } \\
\text { Water }\end{array}$ & $\begin{array}{c}\text { Kuraray Europe GmbH } \\
\text { Germany }\end{array}$ \\
\hline $\begin{array}{l}\text { Fuji Bond LC } \\
\text { (glass ionomer bonding } \\
\text { agent) }\end{array}$ & $\begin{array}{l}\text { Powder: Alumino-silicate glass } 90-100 \% \\
\text { Liquid: Polyacrylic acid } 20-25 \% \\
\text { 2-hydroxyethyl methacrylate (HEMA) } 35-40 \% \\
\text { Proprietary ingredient 5-15\% } \\
\text { 2,2,4-Trimethylhexamethylene dicarbonate 5-7\% } \\
\text { Triethylene glycol dimethacrylate (TEGDMA) 4-6\% }\end{array}$ & $\begin{array}{c}\text { GC-Corporation } \\
\text { Japan }\end{array}$ \\
\hline $\begin{array}{l}\text { Gluma Comfort Bond } \\
\text { (one bottle total etch } \\
\text { bonding agent) }\end{array}$ & $\begin{array}{c}\text { 2-hydroxyethyl methacrylate (HEMA) 35\% } \\
\text { Glutaraldehyde } 5 \% \\
\text { Water }\end{array}$ & $\begin{array}{l}\text { Heraeus Kulzer } \\
\text { Germany }\end{array}$ \\
\hline $\begin{array}{l}\text { NanoBond } \\
\text { (two component, one-step } \\
\text { self- etch system) }\end{array}$ & $\begin{array}{l}\text { Self etching primer: Phosphoric acid, Xanthan gum, } \\
\text { Water, AMPS } \\
\text { Adhesive: 2-hydroxyethyl methacrylate (HEMA) } \\
\text { Trimethylopropane dimethacrylate (TMPTMA) } \\
\text { Pyromellitic glycerol dimethacrylate (PMGDM) } \\
\text { Photo initiator system } \\
\text { Aceton, ethanol } \\
\text { POSS }\end{array}$ & $\begin{array}{c}\text { Jeneric/Pentron Inc. } \\
\text { USA }\end{array}$ \\
\hline
\end{tabular}


by means of the sulforhodamine-B (SRB) assay.

Sulforhodamine B (SRB) colorimetric assay

The sulforhodamine B (SRB) assay was carried out as previously described. ${ }^{14}$ Briefly, the culture medium was aspirated prior to fixation and $75 \mu \mathrm{L}$ of $10 \%$ cold $\left(4^{\circ} \mathrm{C}\right)$ trichloroacetic acid was gently added to the wells. Microplates were left for 30 min at $4^{\circ} \mathrm{C}$, washed five times with deionized water and left to dry at room temperature for at least 24 h. Subsequently, $75 \mathrm{~mL} 0.4 \%$ (w/v) sulforhodamine $\mathrm{B}$ (Sigma) in 1\% acetic acid solution was added to each well and left at room temperature for 20 min. The SRB was removed and the plates were washed five times with $1 \%$ acetic acid before airdrying. Bound SRB was solubilized with $70 \mathrm{~mL}$ $10 \mathrm{mM}$ unbuffered Tris-base solution (E.Merck, Darmstadt, Germanyl and plates were left on a plate shaker for at least $10 \mathrm{~min}$. Absorbance was read at $492 \mathrm{~nm}$ by subtracting the background measurement of $620 \mathrm{~nm}$. The test optical density value was defined as the mean absorbance of each individual well, minus the blank value l'blank' is the mean optical density of the background control wells). Mean values and coefficient of variation (CV) were calculated. The test optical densities were expressed as "survival fractions" that were calculated as the percentages of the control optical density (in the control wells where the plain media were added).

\section{Statistical analysis}

The experiments were performed in six replicates for each dental adhesive, and the experiment was carried out at least twice to ensure reproducibility. One-way analysis of variance (ANOVA) and Tukey multiple comparison tests were used for statistical analyses. Statistical significance was defined as $\mathrm{P}<.05$.

\section{RESULTS}

Figures 1 and 2 show the percentage of viable cells for the adhesives tested in the RPC-C2A and the MRC-5 cell lines, respectively.

In the RPC-C2A cell line, there were statistically significant differences between each adhesive and the negative control $(P<.05)$.

In the MRC-5 cell line, NanoBond and Fuji Bond LC reduced the cell numbers to $98 \%$ and $80 \%$, respectively, and these numbers were not significantly different from the cell number in the negative control. The other four adhesives tested (Admira bond, Gluma Comfort, Clearfil Liner Bond $2 \mathrm{~V}$ and ED Primer II) showed cell numbers that were significantly different from the cell number in the control $(P<.05)$.

In both cell lines, the most toxic effects were observed with Gluma Comfort and Admira Bond. The Gluma Comfort and the Admira Bond reduced the cell numbers to $5 \%$ and $18 \%$, respectively, in the RPC-C2A cell line and $7 \%$ and $19 \%$, respectively, in the MRC-5 cell line. However, in both cell lines, the difference between Gluma Comfort and Admira Bond were not statistically significant ( $P>$.05).

The percentage of viable MRC5 cells exposed to NanoBond was $98 \%$ and thus the cell number did not differ significantly with that in the control. However, the percentage of viable cells with NanoBond was significantly different from the percentages with Clearfil Liner bond 2V, ED Primer II, Admira Bond and Gluma Comfort bond ( $P<.05)$.

In the RPC-C2A cell line, the Fuji Bond LC and the NanoBond showed mild effects in reducing the cell numbers to $73 \%$ and $67 \%$, respectively. The difference between these two adhesives was not statistically significant, but the cytotoxic effects of NanoBond and Fuji Bond LC were significantly higher than those of ED Primer II, Admira bond and Gluma Comfort bond $(\mathrm{P}<.05)$. Of note, the $\mathrm{pH}$ values of the extracts varied between 7.0 and 7.4 , and we did not observe any $\mathrm{pH}$-induced cytotoxicity.

\section{DISCUSSION}

Biocompatibility testing of materials that come in close contact with normal tissues is crucial for the quality of host-to-graft acceptance. Assays measuring cytotoxicity are a critical part of testing materials designed for application on human tissues.

In the present study, we used RPC-C2A and MRC-5 fibroblasts to study the cytotoxic effect of the dental adhesives. Both cell lines have welldefined culturing characteristics in experimental settings and have been previously used. ${ }^{10}$ The selection of established cell lines was desirable because these cell lines were easily maintained in culture, the variability due to different donors was eliminated and greater reproducibility was achievable. Given the fact that cell lines used in experiments in vitro vary in their responses to the same substance, several cell lines should be 
included in a biocompatibility experiment.

The SRB assay that we used for cytotoxicity testing is sensitive, simple, reproducible and shows linearity and a good signal-to-noise ratio. ${ }^{15}$ This method provides a sensitive measure of culture cell protein levels that is linearly correlated with the cell numbers. ${ }^{16}$

The results of the present study showed that different types of dental adhesives had different effects on cells. In the MRC- 5 cell line, the self-etch adhesives (NanoBond, Fuji Bond LC, Clearfil Liner Bond $2 \mathrm{~V}$ and ED primer II) appeared less cytotoxic than the total-etch types (Gluma Comfort Bond and Admira bond). This is in general agreement with the results of previous investigations. ${ }^{8}$

The differential cytotoxicity of the materials tested could be attributed to the different ingredients, the interactions between them and the degree of resin polymerization. It is known that oxygen acts as an inhibitor of monomers' polymerization. It has also been reported that unfilled resin cured in room air has a significantly greater thickness of polymerizationinhibited material than resin cured in an argon atmosphere. ${ }^{17}$ The inhibition layer thickness varies across dentin adhesives and depends on the type and combination of monomers existing in each product. In addition, an aqueous environment may interfere with the polymerization of resinous materials. ${ }^{18}$ Consequently, a relatively high amount of unreacted co-monomers may be released from dental adhesives. Leachable monomers induce the production of intracellular reactive oxidative species (ROS) that can be generated in both healthy and diseased tissues. ${ }^{19,20}$ ROS production has been described by several investigators as an early expression of cellular stress in dental

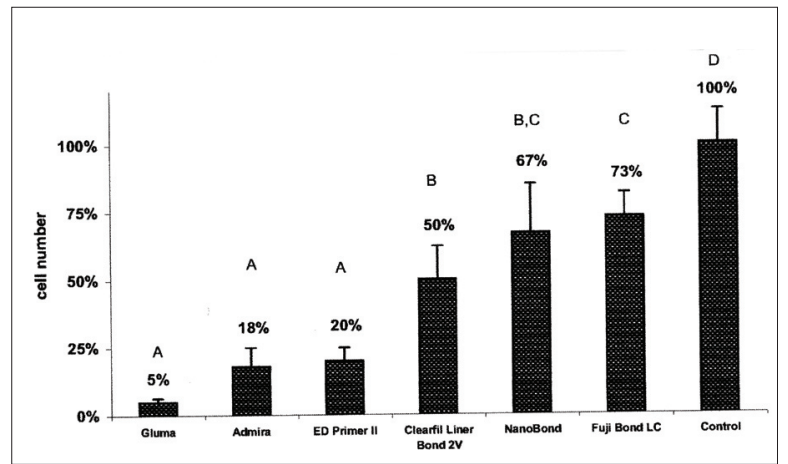

Figure 1. Effect of the dental adhesives on RPC-C2A cells after 24 hours exposure. Bars show mean and standard deviation of sixplicates. Groups identified with the same letter are not significantly different $(P>$.05). monomer cytotoxicity. ${ }^{20}$

Mohsen et $\mathrm{al}^{21}$ found that the cell viability in vitro with either untreated or polished composites correlated with the curing time of the composites by visible light and post-curing time (aging) with heat for ensuring polymerization. They also attributed the increase in the biocompatibility of the polished specimens to the removal of the oxygen-inhibited layer. The oxygen-inhibited layers allow for unreacted double bonds at the surfaces rendering a material toxic, even with long periods of light curing.

In healthy cells, ROS can be produced by the incomplete reduction of oxygen during catabolism. The disruption of important macromolecules through free radical reactions within host cells may hamper cellular functions or may even lead to early cell death. ROS have been shown to cause disruption at multiple cellular sites, resulting in lipid peroxidation, protein oxidation and nucleic acid damage. ROS may induce cell damage directly, or act as intracellular messenger during cell death induced by various other kinds of stimuli. ${ }^{19}$

Ratanasathien et al ${ }^{22}$ assessed the cytotoxicity of the dentin- bonding components in cell cultures and found that the ranking by toxicity was: BisGMA>UDMA>TEGDMA>HEMA (least toxic) after 24 and 72 hours of exposure. In the same study, it was demonstrated that $0.00360 \mathrm{mmol} \mathrm{L}^{-1}$ of HEMA reduced the cell metabolism by $50 \%$ after $24 \mathrm{~h}$ of exposure, whilst Hanks et $\mathrm{al}^{2}$ reported that 16 mmol L ${ }^{-1}$ of HEMA caused an irreversible inhibitory effect when applied to the cells in culture.

HEMA is a common ingredient of dental adhesives to enhance the bond strength to dentin and is present in all adhesives evaluated in the present study (Table 1). Although HEMA was found

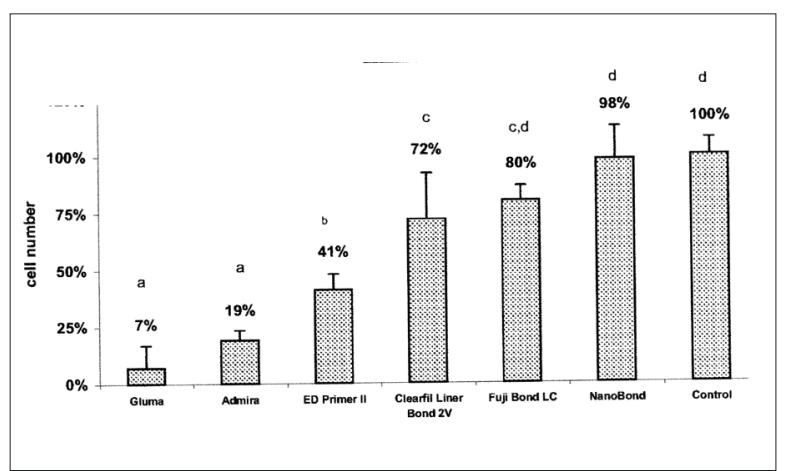

Figure 2. Effect of the dental adhesives on MRC-5 cells after 24 hours exposure. Bars show mean and standard deviation of sixplicates. Groups identified with the same letter are not significantly different ( $P>$.05). 
to be less cytotoxic than the other monomers, its low molecular weight (130.14) and high solubility may result in a greater diffusion of unpolymerized HEMA through dentin.

Our results concerning Gluma Comfort bond are in agreement with previous findings. ${ }^{1,11}$ Hanks et $a^{1}$ examined the nature and levels of metabolic cytotoxicity of the Gluma, Scotchbond 2, glutaraldehyde and HEMA in monolayer cultures and found that glutaraldehyde was much more cytotoxic than HEMA.

Admira bond uses the so-called "ormocer" product, ceramic polysiloxane (silicon-oxygen chains). There have been no published studies on the cytotoxicity of Admira Bond. However, it has been reported that the ormocer restorative material, Admira, was more cytotoxic than two other conventional dimethacrylate composite resins tested. ${ }^{23}$

ED Primer II and Clearfil Liner Bond 2V contain the same phosphate monomer (10-MDP), but the former proved to be significantly more cytotoxic. In a recent in vitro study, Clearfil Protect bond, another 10-MDP-containing adhesive, exhibited a rather mild effect with respect to cytotoxicity. ${ }^{10}$

NanoBond and Fuji Bond LC appeared to be the least cytotoxic materials among the adhesives studied. NanoBond is a one-step self-etch adhesive. It has been reported that due to their high hydrophilicity, one- step adhesives behave as semi-permeable membranes, allowing fluids to penetrate and compromise bond durability, ${ }^{24}$ and incomplete curing of these adhesives can increase their cytotoxicity. Despite these potential limitations, NanoBond showed low cytotoxic effects in the present study. Fuji Bond LC is the only commercially available resin-modified glass ionomer adhesive. Glass ionomer adhesives are self-etching through the use of a relatively high molecular weight $(8,000-15,000)$ polycarboxylbased polymer. Their self-adhesiveness can be attributed to a combination of the micromechanical interlocking and the chemical interaction with the calcium of the residual hydroxyapatite. ${ }^{25-27}$ The chemical interaction may result in bonds that better resist hydrolytic break-down. ${ }^{26}$ The low cytotoxicity of the Fuji Bond LC may be attributed to the high molecular weight of the polycarboxylbased polymer that may not be easily diffused in aqueous conditions. To our knowledge, no data have yet been published on the cytotoxicity of the Fuji Bond LC. However, several in vitro studies assessed the cytotoxicity of glass ionomer cements on cultured cells. The results have been contradictory. Lan et $\mathrm{al}^{28}$ reported that Fuji II LC showed marked cytotoxicity of pulp cells compared with conventional glass ionomer cements. However, other investigators reported that Fuji II LC caused low cytotoxic effects on cultured cells. ${ }^{29}$

It may be unrealistic to correlate the in vitro effects and the clinical performance of dental materials. The differences in experimental conditions of the studies often make it difficult or even impossible to interpret and compare the results, which are sometimes conflicting. It is very important to combine results from both types of experiments to understand the actual clinical effect of materials.

\section{CONCLUSIONS}

Overall, in the cell lines used for the present experiment, cell viability decreased significantly after exposure to the total-etch adhesives.

\section{ACKNOWLEDGMENTS}

This work was in part supported by Procter and Gable Ltd. (AUTh Research Committee project \#81990). The authors wish to thank Prof. S. Kasugai for offering the RPC-C2A cell line.

\section{REFERENCES}

1. Hanks CT, Wataha JC, Parsell RR, Strawn SE. Delineation of cytotoxic concentrations of two dentin bonding agents in vitro. J Endod 1992;18:589-596.

2. Hanks CT, Strawn SE, Wataha JC, Craig RG. Cytotoxic effects of resin components on cultured mammalian fibroblasts. J Dent Res 1991;70:1450-1455.

3. Van Meerbeek B, Perdigao J, Lambrechts P, Vanherle G. The clinical performance of adhesives. J Dent 1998;26:120.

4. Tay FR, Gwinnett AJ, Pang KM. Structural evidence of a sealed tissue interface with a total-etch wet-bonding technique in vivo. J Dent Res 1994;73:629-636.

5. Cox CF, Hafez AA, Akimoto N, Otsuki M, Suzuki S, Tarim B. Biocompatibility of primer, adhesive and resin composite systems on non-exposed and exposed pulps of non-human primate teeth. Am J Dent 1998;11:55-63. 
6. Bouillaguet S, Bertossa B, Krejci I, Wataha JC, Tay FR, Pashley DH. Alternative adhesive strategies to optimize bonding to radicular dentin. J Endod 2007;33:1227-1230.

7. Bouillaguet S, Troesch S, Wataha JC, Krejci I, Meyer JM, Pashley DH. Microtensile bond strength between adhesive cements and root canal dentin. Dent Mater 2003;19:199205.

8. Vajrabhaya L, Pasasuk A, Harnirattisai C. Cytotoxicity evaluation of single component dentin bonding agents. Oper Dent 2003;28:440-444.

9. Chen RS, Liu CC, Tseng WY, Jeng JH, Lin CP. Cytotoxicity of three dentin bonding agents on human dental pulp cells. $J$ Dent 2003;31:223-229.

10. Koulaouzidou EA, Helvatjoglu-Antoniades M, Palaghias G, Karanika-Kouma A, Antoniades D. Cytotoxicity evaluation of an antibacterial dentin adhesive system on established cell lines. J Biomed Mater Res B Appl Biomater 2008;84:271276.

11. Meryon SD, Brook AM. In vitro cytotoxicity of three dentin bonding agents. J Dent 1989;17:279-283.

12. Szep S, Kunkel A, Ronge K, Heidemann D. Cytotoxicity of modern adhesives-In vitro testing on gingival fibroblasts. $J$ Biomed Mater Res 2002;63:53-60.

13. Thumwanit V, Kedjarune U. Cytotoxicity of polymerized commercial cyanoacrylate adhesive on cultured human oral fibroblasts. Aust Dent J 1999;44:248-252.

14. Papazisis KT, Geromichalos GD, Dimitriadis KA, Kortsaris $\mathrm{AH}$. Optimization of the sulforhodamine B colorimetric assay. J Immunol Methods 1997;208:151-158.

15. Vajrabhaya L, Sithisarn P, Wilairat P, Leelaphiwat S. Comparison between Sulphorhodamine-B dye staining and $51 \mathrm{Cr}$-release method in cytotoxicity assay of endodontic sealers. J Endod 1997;23:355-357.

16. Skehan P. Assays of cell growth and cytotoxicity In: Studzinski GP (ed) Cell growth and apoptosis: A practical approach. Oxford: IRL press, 1995: 169-191.

17. Rueggeberg FA, Margeson DH. The effect of oxygen inhibition on an infilled/filled composite system. J Dent Res 1990;69:1652-1658.

18. Spahl W, Budzikiewicz H, Geurtsen W. Determination of leachable components from four commercial dental composites by gas and liquid chromatography/mass spectrometry. J Dent Res 1998;26:137-145.

19. Mates JM, Sanchez-Jimenez FM. Role of reactive species in apoptosis: implications for cancer therapy. Int J Biochem Cell Biol 2000;32:157-170.

20. Engelmann J, Leyhausen G, Leibfritz D, Geurtsen W. Effect of TEGDMA on the intracellular glutathione concentration of human gingival fibroblasts. J Biomed Mater Res 2002;63:746751.
21. Mohsen NM, Craig RG, Hanks CT. Cytotoxicity of urethane dimethacrylate composites before and after aging and leaching. J Biomed Mater Res 1998;39:252-260.

22. Ratanasathien S, Wataha JC, Hanks CT, Dennison JB. Cytotoxic interactive effects of dentin bonding components on mouse fibroblasts. $J$ Dent Res 1995;74:1602-1606.

23. Al-Hiyasat AS, Darmani H, Milhem MM. Cytotoxicity evaluation of dental resin composites and their flowable derivatives. Clin Oral Investig 2005;9:21-25.

24. Tay FR, Pashley DH, Suh BI, Carvalho RM, Itthagarun A. Single-step adhesives are permeable membranes. J Dent 2002;30:371-382.

25. De Munck J, Van Landuyt K, Peumans M, Poitevin A, Lambrechts $P$, Braem M, Van Meerbeek B. A critical review of the durability of adhesion to tooth tissue: methods and results. J Dent Res 2005;84:118-132.

26. Van Meerbeek B, De Munck J, Yoshida Y, Inoue S, Vargas M, Vijay P, Van Landuyt K, Lambrechts P, Vanherle G. Buonocore Memorial Lecture. Adhesion to enamel and dentin: Current status and future challenges. Oper Dent 2003;28:215-235.

27. Yoshida Y, Nagakane K, Fukuda R, Nakayami Y, Okazaki M, Shintani H, Inoue S, Tagawa Y, Suzuki K, De Munck J, Van Meerbeek B. Comparative study on adhesive performance of functional monomers. J Dent Res 2004;83:454-458.

28. Lan WH, Lan WC, Wang TM, Lee YL, Tseng WY, Lin CP, Chang MC, Jeng JH. Cytotoxicity of conventional and modified glass ionomer cements. Oper Dent 2003;28:251259.

29. Oliva A, Della Ragione F, Salerno A, Riccio V, Tartaro G, Cozzolino A, D'AmatoS, Pontoni G, Zappia V. Biocompatibility studies on glass ionomer cements by primary cultures of human osteoblasts. Biomaterials 1996;17:1351-1356. 